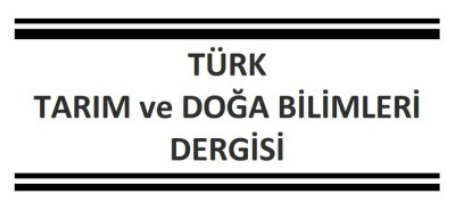

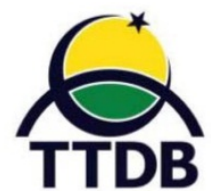

www.dergipark.gov.tr/turkjans Araştırma Makalesi

\title{
TRB1 Bölgesinde (Bingöl, Elazığ ve Malatya İlleri) Elma Yetiştiriciliğinin Mevcut Durumu\&
}

\author{
Ersin KARAKAYA ${ }^{1 *}$, Semiha KIZILOĞLU²
}

${ }^{1}$ Bingöl Üniversitesi, Ziraat Fakültesi, Tarım Ekonomisi Bölümü, Bingöl

${ }^{2}$ Atatürk Üniversitesi, Ziraat Fakültesi, Tarım Ekonomisi Bölümü, Erzurum

*Sorumlu Yazar: karakayaersin1982@gmail.com

Geliş Tarihi: 01.03.2021 Düzeltme Geliş Tarihi: 29.03.2021 Kabul Tarihi: 08.04.2021

\section{Öz}

Bu çalışma; TRB1 Bölgesi'ndeki elma üretimi yapan işletmelerin mevcut durumunun ortaya konularak, pazarlama yapısının tespit edilmesi, işletmelerdeki alet ve makine varlığının belirlenmesi ve bölgedeki elma işletmelerinin sorunlarının belirlenerek çözüm önerileri sunulması amacıyla yapılmıştır. Araştırmada, TRB1 Bölgesi'nde elma üreticiliği yapan işletmelerle 2019 yılı Nisan-Mayıs-Haziran-Temmuz ve Ağustos aylarında yapılmış, yüz yüze gerçekleştirilen anketlerden sağlanan veriler ana materyali oluşturmuştur. Tanımlayıcı istatistikî hesaplamalar yapıldıktan sonra elde edilen veriler çizelge ve şekillere sayı ve oran (\%) şeklinde aktarılmıştır. Ayrıca işletme grupları ile bazı faktörler arasındaki ilişkinin istatistiki olarak önemli olup olmadığını tespit etmek için tek yönlü varyans analizi uygulanmıştır. Çalışma sonuçlarına göre; elma tarımı ile uğraşan bireylerin genelde orta yaş grubunda (41-60 yaş) ve ilkokul mezunu olduğu belirlenmiştir. Elma yetiştiriciliği deneyim süresinin genel tarım deneyim süresi içindeki payı (\%82) dikkate alındığında işletmelerin elma yetiştiriciliği ile birlikte meyve yetiştiriciliğine başladıkları kanısına varılmıştır. Yıllık ortalama elma verimi 627.65 $\mathrm{kg} / \mathrm{da}$ olarak hesaplanmış ve bahçe yaşının artmasıyla yıllık elma veriminin azaldığı sonucuna ulaşılmıştır. Incelenen işletmelerin alet makine varlığı göz önüne alındığında; TRB1 bölgesi elma yetiştiriciliği yapılan işletmelerde makineli tarımın yüksek oranda kullanıldığı kanısına varılmıştır. Yetiştiricilerin genel olarak elma üretimindeki sorunları; pazarlama sorunu içinde elma alıcı sayısının az ve elma satış fiyatının çok düşük olması, girdi fiyatlarının çok yüksek olması, desteklemelerin az veya yetersiz ve gübreleme, ilaçlama konularında teknik bilgi eksikliği olarak belirlenmiştir. Sonuç olarak; TRB1 bölgesinde üretilen elmanın dış pazarlara ihracatı konusunda bölgesel stratejilerin geliştirilmesi gerekmektedir. İlgili kurum ve kuruluşlar ile elma üretimiyle doğrudan ya da dolaylı ilgilenen tarafların katılımıyla çeşitli toplantılar yapılmalı, elma yetiştiriciliği konusunda bölgesel bir vizyon geliştirilmeli ve bu anlamda stratejik amaç ve hedefler belirlenmelidir.

Anahtar kelimeler: TRB1 bölgesi, elma verimi, elma üretim sorunları, çözüm önerileri

\section{Current Situation of Apple Growing in TRB1 Region (Bingol, Elazıg and Malatya Provinces)}

\section{Abstract}

This study; has been carried out in order to determine the current situation of the apple production, the marketing structure, the presence of tools and machinery, the problems of the apple producers and to offer solutions for apple enterprises in the TRB1 Region. In the study, the main material was constituted from the data obtained from face-to-face surveys conducted in April-May-June-July and August 2019 with enterprises engaged in apple growing in TRB1 Region. After descriptive statistical calculations, the data obtained were transferred to tables and figures as numbers and rates (\%). In addition, one-way analysis of variance was applied to determine whether the relationship between enterprises groups and some factors was statistically significant. According to the results of the study; It has been determined that individuals dealing with apple farming are generally in the middle age group (41-60 years) and primary school graduates. Considering the share of apple growing experience time in the overall agricultural experience period (82\%), it is concluded that the enterprises started fruit growing together with apple cultivation. The annual average apple 
yield was calculated as $627.65 \mathrm{~kg} / \mathrm{da}$, and it was concluded that the annual apple yield decreased with the increase of orchard age. Considering the existence of tools and machines of the enterprises examined; It has been concluded that machinery farming is used at a high rate in apple farming enterprises in the TRB1 region. Problems of growers in apple production; low number of apple buyers and very low sales price of apples, very high input prices, low or insufficient support and lack of technical knowledge on fertilization and spraying has been determined in general. As a result; regional strategies should be developed for the export of apples produced in the TRB1 region to foreign markets. Various meetings should be held with the participation of relevant institutions and organizations and parties interested in apple production directly or indirectly, a regional vision on apple cultivation should be developed and strategic goals and objectives should be determined in this sense.

Key words: TRB1 region, apple yield, problems of apple production, offer solutions

\section{Giriş}

Elma; dekar alandan alınan ürün fazlalığı, çok çeşitli olması, soğuk iklim şartlarına dayanıklı olması ve endüstride çok faklı şekillerde değerlendirilebilmesi açısından dünyada yetiştiriciliği yaygın olarak yapılan bir meyvedir ve üretim açısından muz ve üzümden sonra en fazla üretilen üçüncü meyvedir. İçinde birçok vitamin ve mineral bulunduran oldukça faydalı bir meyve olan elmanın ana vatanı Anadolu'yu da içine alan Güney Kafkaslardır. Yetiştiriciliği yapılan elma çeşitlerinin sayısı dünyada 6500'ü aşarken, Türkiye'de ise bu sayı 460 civarındadır (Şenyurt ve ark., 2015). Ekolojik şartların uygunluğu ve gen merkezi olması nedeniyle Türkiye'nin her bölgesinde çok eski yıllardan beri elma yetiştiriciliği yapılmaktadır (Yıkar, 2003; Ertürk ve ark., 2016; Oğuz ve Karaçayır, 2009; Yalçın Sever, 2019).

FAO (2019) yılı verilerine göre; 2015-2019 yılları arasında dünyada elma ekim alanı, üretim ve verim değerleri şekil 1'de verilmiştir. 2015 yılında 5.177.491 ha olan ekim alanı 2019 yılında 4.717.384 ha, 82.408.896 ton olan üretim 2019 yılında 87.236 .221 ton ve $159.168 \mathrm{~kg} / \mathrm{ha}$ olan verim ise 2019 yılında $184.925 \mathrm{~kg} / \mathrm{ha}$ olarak gerçekleşmiştir (Şekil 1).

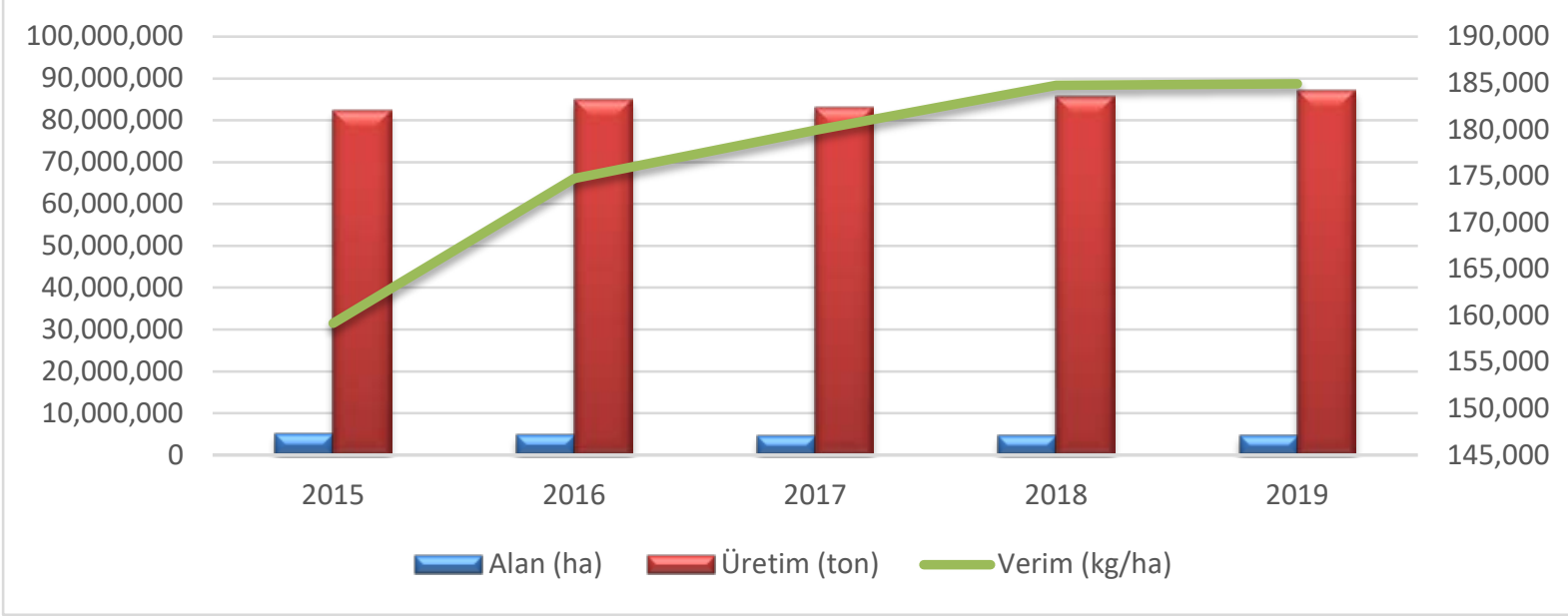

Şekil 1. 2015-2019 yılları dünya elma ekim alanı, üretim ve verim değerleri

2019 yılında 42.426 .578 ton üretim ile Çin ilk sırada yer alırken, 12.044 .780 ton ile $A B 2$. sırada, 4.997.680 ton ile ABD 3. sırada ve 3.618.752 ton ile Türkiye 4. sırada yer almıştır. Dünya elma ekim alanı itibariyle Çin 2.041.197 ha alan ile dünya ülkeleri içinde ilk sırada olmakla birlikte diğer ülkelerin ekim alanı birbirine yakındır. Elma verimi bakımından dünya ülkelerinin durumuna bakıldığında ABD $420.468 \mathrm{~kg} / \mathrm{da}$ ile ilk sırada, Çin $207.851 \mathrm{~kg} / \mathrm{da}$ ile 2. sırada ve Türkiye ise 207.451 $\mathrm{kg} / \mathrm{da}$ ile 3. sırada yer almaktadır (Şekil 2). 


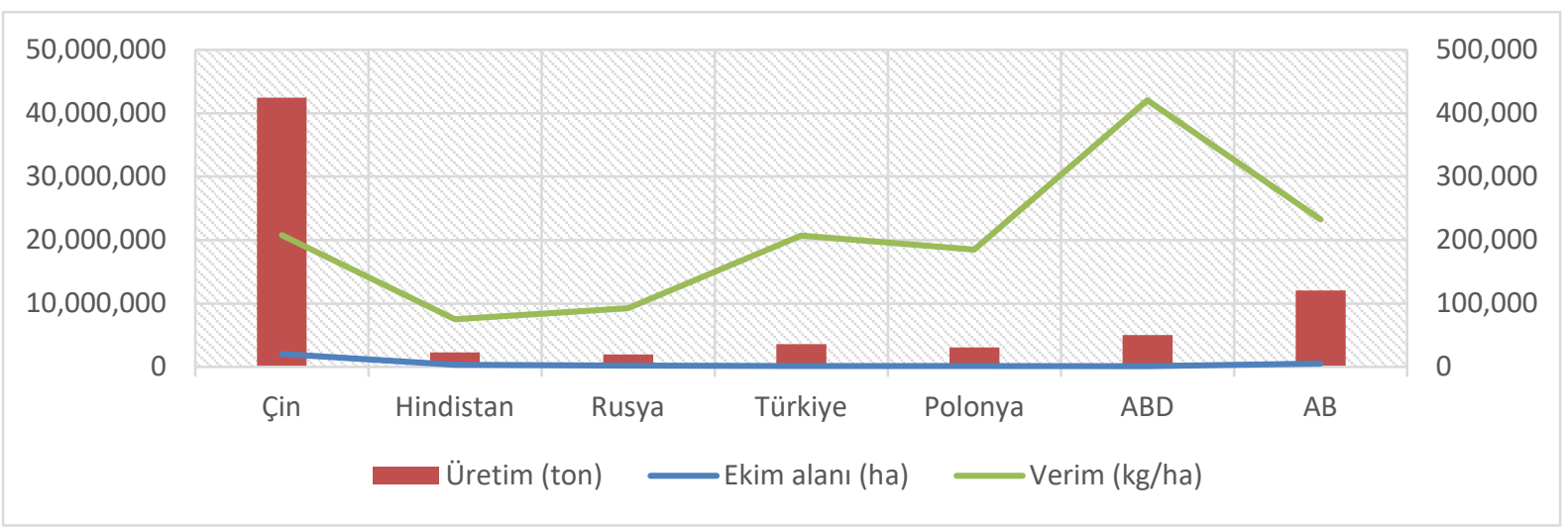

Şekil 2. 2019 yılı elma ekim alanı, üretim ve verim değerleri bakımından öne çıkan ülkeler

Şekil 3'te Türkiye'de 2019 yılında toplam elma üretimi, meyve veren ağaç sayısı ve toplam verim değerleri açısından önemli potansiyeli olan iller verilmiştir. Elma üretiminin en fazla yapıldığı il Isparta'dır. Isparta'da 2019 yılında 732 bin ton elma üretimi ile toplam elma üretiminin \%20'si gerçekleşmiştir. Isparta ilini 485 bin ton ile Karaman ve 438 bin ton ile Niğde illeri takip etmektedir. Türkiye'de mevcut elma ağaç sayısı 80 milyon civarında iken meyve veren ağaç sayısı Karaman ilinde 9 milyon, Niğde ilinde 8 milyon, Konya ve Isparta'da 6 milyon ve Antalya'da 4 milyon adet olarak belirlenmiştir. Meyve veren ağaç başına ise en fazla verim $418 \mathrm{~kg}$ ile Isparta ilinde gerçekleşmiştir.

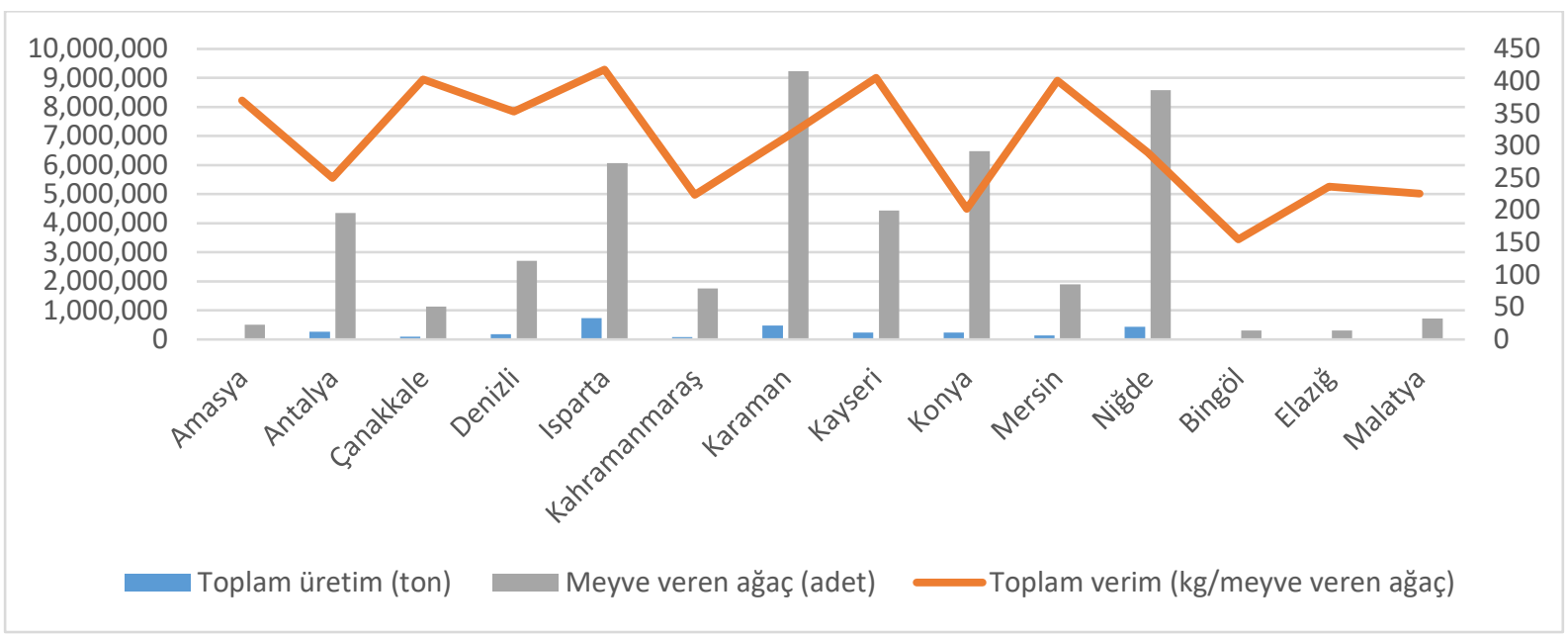

Şekil 3. Türkiye'de iller itibariyle 2019 yılı toplam elma üretimi, meyve veren ağaç sayısı ve toplam verim

2019 yılında Türkiye elma ihracatı \%7 düzeyinde 256 bin ton olarak gerçekleşmiş ve 90 milyon \$ ihracat geliri elde edilmiştir. Elma ithalatı ise 280 ton olarak gerçekleşmiş ve 193 bin \$ ithalat ücreti ödenmiştir. Türkiye, birçok meyve türünde olduğu gibi elmada da \%127.5 oran ile kendine yeten bir ülke konumundadır (TUIK, 2019). İlaveten son yıllarda elma üretiminde yaşanan artışa paralel olarak tarımsal alt yapının gelişmesi, sertifikalı fidan üretiminin çoğalmasıyla elma veriminde de artışlar yaşanmaktadır.

Bu çalışma; TRB1 Bölgesi'ndeki elma üretimi yapan işletmelerin mevcut durumunun ortaya konularak, pazarlama yapısının tespit edilmesi, işletmelerdeki alet ve makine varlığının belirlenmesi ve bölgedeki elma işletmelerinin sorunlarının belirlenerek çözüm önerileri sunulması amacıyla yapılmıştır.

\section{Materyal ve Metot Materyal}

Araştırmada, TRB1 Bölgesi'nde Bingöl, Elâzığ ve Malatya illerinde elma üreticiliği yapan işletmelerle yüz yüze gerçekleştirilen anketlerden sağlanan veriler ana materyali oluşturmuştur (Şekil 4). Tarım ve Orman Bakanlığı kayıtlarından, Türkiye İstatistik Kurumu (TÜiK) ve Food and Agriculture Organization of the United Nations (FAO) 
tarafından yayımlanan istatistik verileri ve daha önceden yapılmış konuyla alakalı tez çalışmaları, araştırma makaleleri, araştırma raporları gibi ikincil verilerle çalışma desteklenmiştir. Anket çalışması 2019 yılı Nisan-Mayıs-Haziran-Temmuz ve Ağustos aylarında yapılmış, toplanan veriler 2018-2019 üretim dönemine aittir.

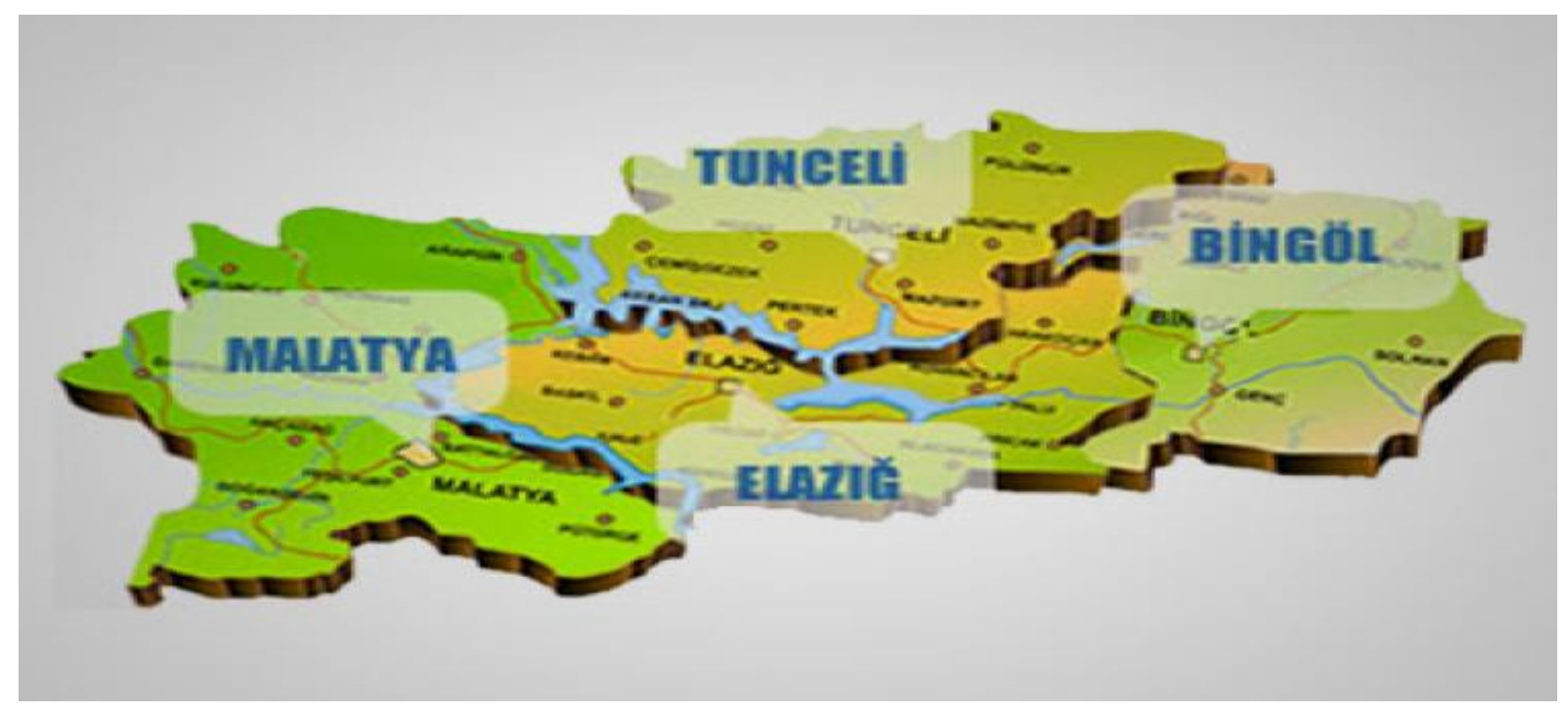

Şekil 4. Türkiye istatistiki bölge birimleri sınıflandırması- Düzey 2

\section{Yöntem}

Yapılan ön incelemeler neticesinde, araştırma bölgesinde, populasyonu oluşturan tarım işletmelerinde kayıt tutulmadığından, Türkiye genelinde olduğu gibi yüz yüze anket yapılması tercih edilmiş ve tarımsal, sosyo- ekonomik araştırmalarda çoğunlukla kullanılan yatay kesiti verileriyle çalışılmıştır.

\section{Örnekleme Aşamasında Kullanılan Yöntem}

Araştırma kapsamında örnekleme çerçevesinin oluşturulması amacıyla Malatya, Elazığ ve Bingöl il Tarım ve Orman Müdürlükleri Çiftçi Kayıt Sisteminden yararlanılarak, ilçeler ve ilçelere bağlı köylerin isimleri ve bu köylerdeki tarım işletmesi sayıları ve işletme büyüklüklerine ait veriler temin edilmiştir. Malatya iline bağı 611 , Elazığ iline bağlı 640, Bingöl iline bağlı 297 köy olduğu tespit edilmiştir. Anket uygulanacak tarım işletmesi sayısının hesaplanmasında tabakalı tesadüfi örnekleme metodundan, yararlanılmıştır. Araştırma bölgesindeki tarım işletmelerinin arazi büyüklüklerinin dağılımına göre 1-50 dekar olanlar (birinci grup), 51-100 dekar olanlar (ikinci grup), 101 dekardan daha fazla olanlar (üçüncü grup) olmak üzere üç tabaka olarak belirlenmiştir. İşletme sayısı birinci tabakada 3129, ikinci tabakada 1571, üçüncü tabakada 1304 olarak hesaplanmıştır. Birinci tabakanın standart sapması
12,63, ikinci tabakanın standart sapması 14,29, üçüncü tabakanın standart sapması 121,89 olarak hesaplanmıştır. Anket yapılan işletme sayısı, Tabakalı tesadüfî örnekleme yöntemine göre \%10 hata payı ve \%95 güven aralığında 223 adet olarak belirlenmiştir. Örnek işletmelerin 116 âdeti birinci gruba, 59 âdeti ikinci gruba, 48 âdeti üçüncü gruba düşmüştür. Araştırma kapsamında Bingöl iline bağlı 8 köyde 18 adet, Elazığ iline bağlı 29 köyde 73 adet, Malatya iline bağlı 24 köyde 132 adet olmak üzere toplam 223 adet anket yapılmıştır. Tesadüfi sayılar tablosu esas alınarak anket yapılan işletmelerin seçimi gerçekleştirilmiştir.

Tabakalı tesadüfi örnekleme yöntemine göre kullanılan formüller aşağıda verilmiştir (Çiçek ve Erkan, 1996)

$n=\frac{\mathrm{N} \Sigma\left[\mathrm{N}_{\mathrm{h}}\left(\mathrm{S}_{\mathrm{h}}\right)^{2}\right]}{\mathrm{N}^{2} \mathrm{D}^{2}+\sum \mathrm{N}_{\mathrm{h}}\left(\mathrm{S}_{\mathrm{h}}\right)^{2}}$ ve $n_{i}=\frac{\mathrm{N}_{\mathrm{h}}}{\sum \mathrm{N}_{\mathrm{h}}} * \mathrm{n}$

Formülde:

$\mathrm{D} 2=(\mathrm{d} / \mathrm{Z}) 2$

$\mathrm{d}=$ Ortalamadan belli bir yüzde sapma

$\mathrm{Z}=$ Serbestlik derecesine ait tablo değeri

$\mathrm{Nh}=\mathrm{h}$. tabakada yer alan işletme sayısı

$\mathrm{Sh}=\mathrm{h}$. tabakaya ait standart sapma değeri

Sh2 $=$ h. tabakaya ait varyans değeri

$\mathrm{N}=$ Populasyon hacmi

$\mathrm{ni}=$ Tabakadaki örnek sayısı

$\mathrm{n}=$ Örnek hacmi 


\section{İ̧̧letmecilerin Tarım Uygulamaları ve Görüşlerinin Analizinde Uygulanan Yöntem}

Üreticilerin toprak tahlili yaptırma durumları, gübre ve ilaç kullanımlarına ilişkin görüşleri, tarımda bazı uygulamalara ilişkin görüşleri, üretici örgütlerine üyelik durumları ve bunlara ilişkin görüşleri hakkında bilgiler alınmış ve toplanan bilgiler detaylı şekilde excel dosyasına işlenip kontrol edildikten sonra analiz işlemi Statistical Package for the Social Sciences (SPSS) istatistik paket programı kullanılarak gerçekleştirilmiştir. Tanımlayıcı istatistikî hesaplamalar yapıldıktan sonra elde edilen veriler çizelge ve şekillere sayı ve oran (\%) şeklinde aktarılmıştır. Ayrıca işletme grupları ile bazı faktörler arasındaki ilişkinin istatistiki olarak önemli olup olmadığını tespit etmek için tek yönlü varyans analizi uygulanmıştır. Tek yönlü varyans analizi sonucunda farklılığın hangi gruplar arasında olduğunu tespit etmek için Duncan testinden yararlanılmıştır.

\section{Bulgular ve Tartışma}

Elma Yetiştiricilerinin Sosyo Demografik Özellikleri İncelenen işletme sahiplerinin tamamının erkek olduğu belirlenmiştir. Anket yapılan işletmecilerin yaşlarının 23 ile 70 arasında değiştiği ve ortalamasının 48.9 olduğu belirlenmiştir. İşletmecilerin \%85.3'ünün 41-60 yaş aralığında, \%9.6'sının 20-40 yaş aralığında ve \%5.1'inin ise 61 yaş ve üstü grubunda olduğu belirlenmiştir (Çizelge 1). Daha önce Binici ve ark (2006), Kaçıra (2007), Armağan ve Özden (2007), Aydoğmuş ve Yılmaz (2010), Gözener (2013), Aydın (2014), Hazneci (2015), Ulu ve ark (2016), Çakırlı (2017), Gence (2019), Abdul- Kareem (2015), Alemu ve ark (2017), Ma ve ark (2018) ve Osmani ve Kambo (2019) tarafından yapılan çalışmalarda tarım üreticilerinin yüksek oranda 40 yaşından büyük oldukları sonucu saptanmıştır. Çalışma bulguları daha öce yapılan bu çalışma bulgularıyla paralellik göstermekte tarımla uğraşan bireylerin genel olarak orta yaş grubunda (40 yaşın üstünde) olduğu kanısına varılmıştır.

Çizelge 1. İşletmecilerin yaş grupları itibariyle dağılımı (\%)

\begin{tabular}{lcccc}
\hline ì & \multicolumn{4}{c}{ Yaş grupları } \\
\cline { 2 - 4 } & $\mathbf{2 0 - 4 0}$ & $\mathbf{4 1 - 6 0}$ & $\mathbf{6 1}$ ve üstü & Toplam \\
\hline Bingöl & 11.1 & 77.8 & 11.1 & 100 \\
Elazı̆̆ & 12.5 & 83.3 & 4.2 & 100 \\
Malatya & 5.3 & 94.7 & 0 & 100 \\
Ortalama & 9.6 & 85.3 & 5.1 & 100 \\
\hline
\end{tabular}

İncelenen işletmecilerin eğitim durumlarının iller itibariyle dağılımı Çizelge 2'de verilmiştir. Illkokul mezunu olan işletmecilerin oranı \%76.2, ortaokul mezunu olan işletmecilerin oranı \%8.1, lise mezunu olan işletmecilerin oranı \%14.3, okuryazar olan işletmecilerin oranı \%0.9 ve üniversite mezunu olan işletmecilerin oranı ise $\% 0.4$ olarak belirlenmiştir. Bayramoğlu ve Bozdemir (2018), Gence (2019), Kaçıra (2007) ve Hazneci (2015) tarafından yapılan çalışmalarda da üreticilerin eğitim seviyeleri yüksek oranda ilkokul mezunu olarak bildirilmiştir.

Çizelge 2. İşletmecilerin eğitim durumlarının iller itibariyle dağılımı (\%)

\begin{tabular}{lcccccc}
\hline il & \multicolumn{5}{c}{ Eğitim durumu } \\
\cline { 2 - 7 } & Okuryazar & ilkokul & Ortaokul & Lise & Üniversite & Toplam \\
\hline Bingöl & 11.1 & 44.4 & 27.8 & 11.1 & 5.6 & 100 \\
Elazı̆ & 0 & 68.1 & 12.5 & 19.4 & 0 & 100 \\
Malatya & 0 & 85 & 3 & 12 & 0 & 100 \\
Ortalama & 0.9 & 76.2 & 8.1 & 14.3 & 0.4 & 100 \\
\hline
\end{tabular}


Incelen işletmelerin aile birey sayısı 2 ile 7 kişi arasında değişmekte ve ortalama olarak 4.13 olarak hesaplanmıştır. Bingöl ilinde incelenen işletmelerin \%27.8'inin 4 kişilik, \%27.6'sının ise 6 kişilik ailelerden, Elâzığ ilindeki işletmelerin \%51.4'ünün ve Malatya ilindeki işletmelerin ise \%61.7'sinin 4 kişilik ailelerden oluştuğu belirlenmiştir. Genel ortalama olarak işletmelerin \%46.9'unda ailedeki birey sayısının 4 kişi olduğu sonucuna ulaşılmıştır (Çizelge 3). Gözener (2013), Aydın (2014), Hazneci (2015), Ulu ve ark (2016), Çakırlı (2017), Bayramoğlu ve Bozdemir (2018) ve Gence (2019) tarafından yapılan çalışmalarda da aile genişliği ortalaması yüksek oranda 4 kişi ve biraz üstünde olarak hesaplanmıştır.

Çizelge 3. iller itibariyle işletmelerdeki aile üye sayısının dağılımı (\%)

\begin{tabular}{lccccccc}
\hline il & \multicolumn{7}{c}{ Ailedeki birey sayısı (kişi) } \\
\cline { 2 - 8 } & $\mathbf{2}$ & $\mathbf{3}$ & $\mathbf{4}$ & $\mathbf{5}$ & $\mathbf{6}$ & $\mathbf{7}$ & Toplam \\
\hline Bingöl & 5.6 & 16.7 & 27.8 & 16.7 & 27.6 & 5.6 & 100 \\
Elazı̆ & 18.1 & 15.3 & 51.4 & 13.9 & 1.3 & 0 & 100 \\
Malatya & 0.8 & 6.8 & 61.7 & 20.3 & 10.4 & 0 & 100 \\
Ortalama & 8.3 & 12.9 & 46.9 & 16.9 & 13.2 & 1.8 & 100 \\
\hline
\end{tabular}

Yetiştiricilerin genel tarım deneyimi ve elma yetiştiriciliği deneyimi Çizelge 4'te verilmiştir. Yetiştiricilerin genel ortalama itibariyle genel tarım deneyimi yaklaşık olarak 19 yıl, elma yetiştiriciliği deneyimi ise 16 yıl olarak belirlenmiştir. Bingöl ilindeki yetiştiricilerin hem genel tarım hem de elma tarımında Elâzığ ve Malatya illerine göre yıl olarak daha fazla deneyimli oldukları görülmüştür. Incelenen işletmelerde iller itibariyle hem genel tarım hem de elma tarımı deneyim süreleri ortalamaları arasındaki farklar istatistiki olarak önemli çıkmıştır. Genel tarım deneyiminde Bingöl ili ilk sırada iken istatistiki olarak aynı grupta yer alan Malatya ve Elâzığ illeri ikinci sırada olarak belirlenmiştir. Elma yetiştiriciliği deneyimin de ise istatistiki olarak aynı grupta yer alan Bingöl ve Malatya illeri ilk sırada, Elazığ ilinin ise bu iki ili takip ettiği belirlenmiştir. Elma yetiştiriciliği deneyim süresinin genel tarım deneyim süresi içindeki payı \%82 olarak hesaplanmıştır. Genel tarımsal deneyim süresi Armağan ve Özden (2007) ve Hazneci (2015) tarafından 32 yıl, Çakırlı (2017) tarafından 33 yıl, Gence (2019) tarafından ise 27.1 yıl olarak bildirilmiştir. Çalışmada bulduğumuz değer daha önceki çalışmalarda bulunan değerden düşük çıkmıştır. Daha önce yapılan çalışmalarda elma yetiştiriciliği süresini Alemu ve ark (2017) Gana'da 10.2 yıl, Osmanı ve Kambo (2019) ise Arnavutluk'ta 11.4 yıl olarak bildirmişlerdir. Elma yetiştirime süresi Gana ve Arnavutluk ülkelerine göre yüksek çıkmıştır.

Çizelge 4. İşletmecilerin tarımsal deneyimi

\begin{tabular}{|c|c|c|c|c|}
\hline \multirow[t]{3}{*}{ iller } & \multicolumn{4}{|c|}{ Tarımsal deneyim (yıl) } \\
\hline & \multicolumn{2}{|c|}{ Genel tarım } & \multicolumn{2}{|c|}{ Elma tarımı } \\
\hline & Ortalama & Standart hata & Ortalama & Standart hata \\
\hline Bingöl & $26.89^{b}$ & 2.513 & $18.06^{b}$ & 2.638 \\
\hline Elazı̆̆ & $17.44^{\mathrm{a}}$ & 0.826 & $12.38^{\mathrm{a}}$ & 0.717 \\
\hline Malatya & $19.09^{a}$ & 0.515 & $17.38^{b}$ & 0.597 \\
\hline Ortalama & 19.19 & 0.479 & 15.82 & 0.498 \\
\hline F ve P Değeri & \multicolumn{2}{|c|}{14.067 ve 0.000} & \multicolumn{2}{|c|}{12.667 ve 0.000} \\
\hline
\end{tabular}


İncelenen işletmelerin genel ortalama itibariyle \%92.4'ünde ikinci ürün yetiştirildiği, \%7.6'sında ise sadece elma yetiştirildiği belirlenmiştir. Bingöl'de incelenen işletmelerin yarısında sadece elma yarısında ise elma ile birlikte başka ürün ya da ürünler de yetiştirildiği, Malatya ilinde ise bir işletmenin sadece elma yetiştirdiği sonucu ortaya çıkmıştır. İşletmede üretilen ikinci ürünlerin Bingöl ilinde daha çok ceviz, sebze ve yem bitkileri, Elâzığ ilinde kayısı, üzüm, ceviz ve sebze, Malatya ilinde ise kayısı, ceviz ve badem olduğu tespit edilmiştir. iller itibariyle genel ortalamaya bakıldığında incelenen işletmelerin \%70'inde tarım dışı çalışma yapılmadığı, \%30'unda ise tarım dışı çalışma yapıldığı sonucu saptanmıştır. Iller itibariyle özellikle Elâzığ ilindeki işletmelerde diğer illere nazaran tarım dışı çalışma yapılma oranı daha yüksek olarak bulunmuştur. Incelenen işletmelerde işletme sahiplerinin \%70'inin asıl işi çiftçi olarak belirlenirken diğer mesleklerin dağılımı Şekil 5'te verilmiştir. Asıl işi esnaflık olan işletmecilerin oranı \%12.1, memur olanların oranı \%9.5, kamuda sürekli işçi olanların oranı \%4.4, özel sektörde sürekli işçi olanların oranı \%2.7 ve emekli olanların oranı ise \%1.3 olarak belirlenmiştir. İşletmedeki nüfusun \%69.3'ünün sosyal güvence durumunun Bağ-Kur, \%27.9'unun SGK, \%1.9'unun sosyal güvence durumunun olmadığı ve \%0.9'unun ise emekli sandığı olduğu belirlenmiştir. Tarım dışı çalışma yapılma oranı, Karaçayır (2010) tarafından \%24.1, Gözener (2013) tarafından \%12.5, Bayramoğlu ve Bozdemir (2018) tarafından \%38 ve Aytop ve Akbay (2018) tarafından \%42.95 olarak bildirilmiştir.

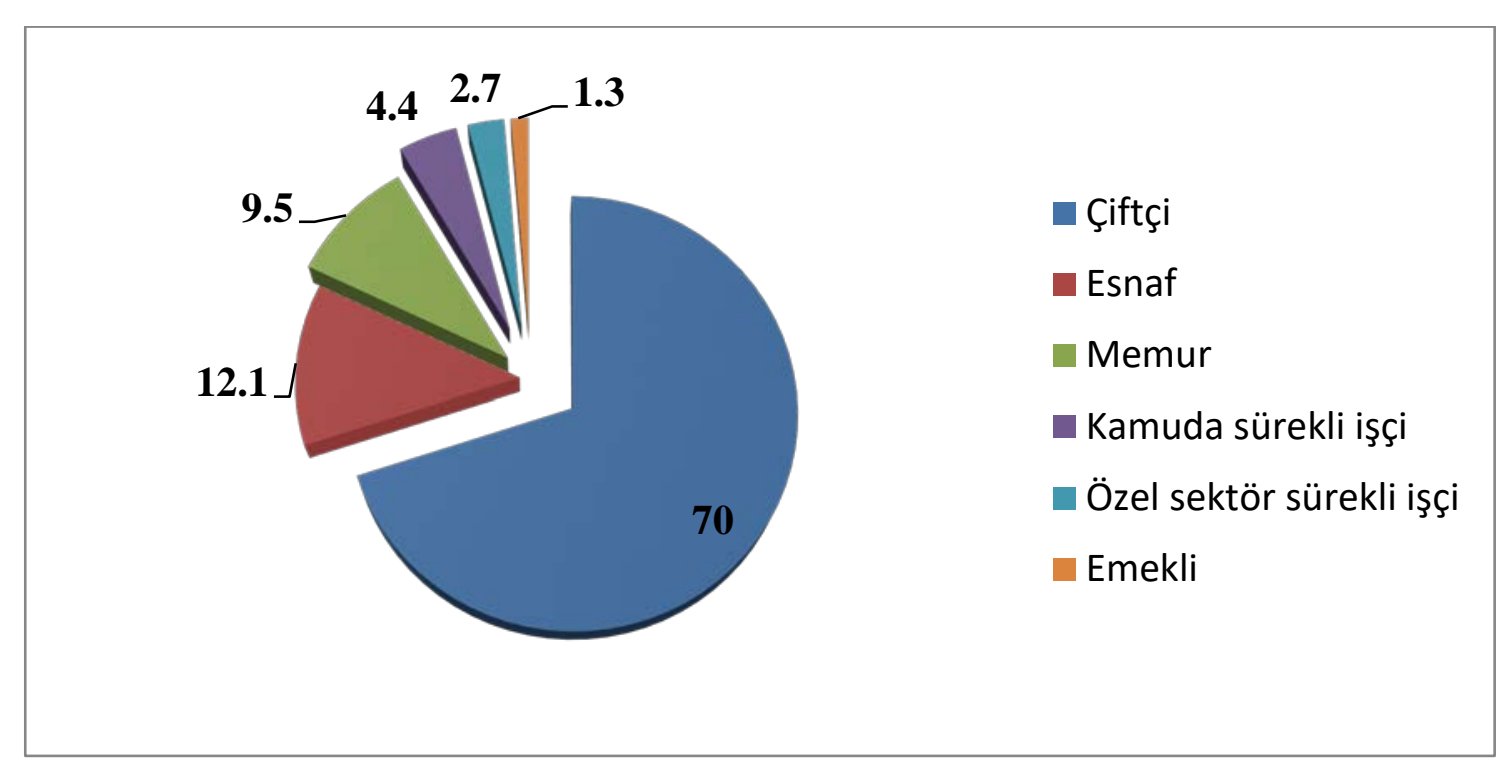

Şekil 5. İşletme sahibinin asıl iş durumunun dağılımı (\%)

\section{Işletmelerdeki Elma Arazisinin Genel Özellikleri}

İşletmede elma yetiştirilen arazinin genel yapısal özellikleri (alanı, bahçe yaşı, arazinin mülkiyet durumu, arazi topografyası, toprak yapısı, toprak verimi ve sulama durumu) ve yıllık verim değerleri analiz edilmiştir. İncelenen işletmelerde elma yetiştiriciliği yapılan alanın, $\% 45.3$ oranında 1$20 \mathrm{da}$ \%35 oranında 21-40 da ve \%19.7 oranında ise 41 da ve üzerinde olduğu belirlenmiştir. Kaynaş ve ark (2009) Çanakkale ilinde elma bahçelerinin genellikle 10 da'ın altında olduğunu bildirmişlerdir. İncelenen işletmelerde elma bahçesinin ortalama yaşı 11.6 yıl olarak belirlenirken, Bingöl ilindeki elma bahçelerinin yaşı 15.3 yıl, Elâzığ ilindeki bahçelerin yaşı 9 yıl ve Malatya ilindeki bahçelerin yaşı ise 12.5 yıl olarak belirlenmiştir. Yapılan analizde iller itibariyle elma bahçeleri yaşının ortalamaları arasındaki farklar istatistiki olarak önemli bulunmuş $(p<0.05)$, Elâzığ ilindeki elma bahçelerinin Malatya iline göre, Malatya ilindeki elma bahçelerinin ise Bingöl ilindeki bahçelere göre daha genç yaşta oldukları sonucuna varılmıştır. Elma arazisinin mülkiyet durumu incelendiğinde işletmelerin \%96,4'ünde arazinin işletme sahibinin kendi mülkü olduğu, \%3.6'sında ise arazinin ortağa tutulduğu belirlenmiştir. Özellikle Elâzığ ilindeki işletmelerde Malatya ilindeki işletmelere nazaran arazinin ortağa tutulma oranı biraz daha yüksektir. Bingöl ilindeki elma arazilerinin tamamının işletme sahibinin kendi mülkü olduğu saptanmıştır. Konya'da Arısoy ve Oğuz (2005) tarafından yapılan çalışmada işletmelerin \%79.3'ünde arazinin işletmecinin kendi mülkü olduğu, Karaçayır (2010)'ın Karaman'da yaptığı çalışmada da arazi kullanım şekli olarak mülk sahibi oranının yüksek çıktığı belirlenmiştir. Tarımsal işletme yapı 
araştırmasına göre (TÜik 2010) işletmelerde arazi kullanım şekli olarak \%96 oranında mülk arazi kullanım şekli, Aydın (2014) ise Trakya bölgesi için bu oran \%76.7 olarak belirlenmiştir. Incelenen arazilerin \%85.7'sinin düz, \%9.9'unun hafif engebeli, \%3.6'sının orta engebeli ve \%0.9'unun ise çok engebeli olduğu belirlenmiştir. Özellikle Elâzığ'daki elma bahçelerinin tamamının topoğrafyasının düz olduğu, çok engebeli topoğrafyaya sahip olan 2 adet işletmenin ise Bingöl ilinde olduğu sonucuna ulaşılmıştır. Toprak yapısı taşlı olan arazilerin oranı \%11.7, taban olan arazilerin oranı \%21.5, killi olan arazilerin oranı $\% 9.9$, kıraç olan arazilerin oranı $\% 22$ ve sulu olan arazilerin oranı ise \%35 olarak belirlenmiştir. Arazi sahiplerinin beyanlarına göre Bingöl'deki arazilerin genel itibariyle toprak yapısının taşlı, Elâzığ'daki arazilerin kıraç ve Malatya'daki arazilerin ise sulu olduğu sonucuna varılmıştır. Çok yüksek toprak verimi olan arazilerin oranı \%33.2, yüksek verimi olanların oranı $\% 35$, orta verimi olanların oranı \%25.1, düşük verimi olanların oranı \%0.9 ve çok düşük verimi olanların oranı ise $\% 5.8$ olarak tespit edilmiştir. Toprak verimi çok yüksek ve yüksek olan arazilerin çoğunlukla Malatya ilinde, orta verimli toprakların Elâzığ'da ve çok düşük verimli toprakların ise Bingöl ilinde olduğu sonucu ortaya çıkmıştır. Incelenen işletmelerin tamamında arazinin sulandığı belirlenmiştir. Bahçe yaşının artmasıyla yıllık elma veriminin azaldığı ve bu durumun istatistiki olarak önemli olduğu sonucu ortaya çıkmış, yıllık elma verimi, 10 yıldan küçük olan bahçelerde 693.8, 10-20 yıl olan bahçelerde 554 , ve 21 yıl ve üzerinde olan bahçelerde ise 433.3 $\mathrm{kg} / \mathrm{da}$ olarak gerçekleşmiştir (Çizelge 5). Yıllık ortalama elma verimi; Gül (2005) ve Aydoğmuş ve Yılmaz (2010) tarafından Antalya'da $2426.4 \mathrm{~kg} / \mathrm{da}$ ve $2832 \mathrm{~kg} / \mathrm{da}$, Demircan ve ark (2005) tarafından Isparta'da $2939 \mathrm{~kg} / \mathrm{da}$, Kaya ve ark (2009) tarafından 2007 yılı için 400 kg, 2008 yılı için ise 700 kg, Bayramoğlu ve ark (2009) tarafından Konya'da 663 kg/da, Karaçayır (2010) tarafından Karaman'da 1975 kg/da, Ertürk ve ark (2016) tarafından Iğdır'da $114 \mathrm{~kg} / \mathrm{da}$, Erdoğan ve ark (2016) tarafından Isparta'da 4877. kg/da, Kanat ve ark (2017) tarafından Konya'da yarı bodur elma bahçeleri için 1947, bodur bahçeler için ise 2872 $\mathrm{kg} / \mathrm{da}$, Çelik ve Karakaya (2017) tarafından Bingöl'de $476.9 \mathrm{~kg} /$ da olarak hesaplanmıştır. Çin'de yapılan bir çalışmada dekara elma verimi $1152.8 \mathrm{~kg}$ olarak hesaplanmıştır (Bai ve ark 2019).

Çizelge 5. İncelenen işletmelerde bahçe yaşı itibariyle yıllık elma verimi

\begin{tabular}{lccc}
\hline Bahçe yaşı (yıl) & \multicolumn{3}{c}{ Yılık elma verimi (kg/da) } \\
\cline { 2 - 4 } & Ortalama & Standart sapma & Standart hata \\
\hline 10 yıldan küçük & $693.88^{\mathrm{c}}$ & 514.620 & 46.978 \\
$10-20$ yıl & $554.00^{\mathrm{b}}$ & 306.798 & 30.680 \\
21 yıl ve üzeri & $433.33^{\mathrm{a}}$ & 115.470 & 66.667 \\
Ortalama & 627.65 & 435.178 & 29.142 \\
\hline
\end{tabular}

$F$ ve $P$ değeri

\section{incelenen Işletmelerde Alet-Makine Varlı̆ı̆}

Tarımsal işletmelerde tarımsal alet ve makinelerin varlığı hem işletmenin hem de bölgenin gelişmişlik seviyesini gösteren bir ölçüttür (Çakırlı 2017). Incelenen işletmelerin \%72.6'sında 1 adet traktör, \%70'inde 1 adet pulluk, \%72.2'sinde 1 adet römork, \%48'inde 1 adet motopomp, \%40.8'inde 1 adet çapa makinesi, \%30.5'inde 1 adet holder, \%25.6'sında 1 adet kültivatör, \%3.1'inde 1 adet Mibzer ve \%0.9'unda ise 2 adet ot biçme makinesi olduğu belirlenmiştir. Iller itibariyle Bingöl ilinde traktör varlığının diğer illere nazaran daha az

\subsection{2 ve 0.043}

olduğu belirlenmiştir. Traktör varlığı Bingöl'de \%38.8, Elâzığ'da \%56.1 ve Malatya'da \%86.3 olarak tespit edilmiştir (Çizelge 6). Çakırlı (2017) Mersin'de yaptığı çalışmada, ankete katılan tüm işletmelerin kendine ait bir traktöre sahip olduğunu bildirmiştir. Mesci (2018) ve Mesci ve Karlı (2018) tarafından Isparta'daki işletmelerde traktör sayısının ortalama olarak 0.65 olduğu belirlenmiştir. Gence (2019) tarafından Kahramanmaraş'ta işletmelerin \%90.1'inin kendi tarımsal alet - makinesini kullandığı ve üreticilerin \%91.5'inin kendi traktörü olduğu belirlenmiştir. 
Çizelge 6. iller itibariyle traktör varlığının dağılımı

\begin{tabular}{lcccccccc}
\hline \multirow{2}{*}{ Traktör varlığı (\%) } & \multicolumn{2}{c}{ Bingöl } & \multicolumn{2}{c}{ Elâzı̆̆ } & \multicolumn{2}{c}{ Malatya } & \multicolumn{2}{c}{ Ortalama/Toplam } \\
\cline { 2 - 9 } & Sayı & $\%$ & Sayı & $\%$ & Sayı & $\%$ & Sayı & $\%$ \\
\hline Evet & 7 & 38.8 & 41 & 56.1 & 114 & 86.3 & 162 & 72.6 \\
Hayır & 11 & 61.2 & 32 & 43.9 & 18 & 13.7 & 61 & 27.4 \\
Toplam & 18. & 100.0 & 73 & 100.0 & 132 & 100.0 & 223 & 100.0 \\
\hline
\end{tabular}

Elma Yetiştiriciliği Yapılma Nedeni ve Yetiştiriciliği Yapılan Elmanın Çeşit Özellikleri

Incelenen işletmelerde alışkanlıktan dolayı elma yetiştiren üretici oranı $\% 58$, hobi, zevk için elma yetiştiren üretici oranı $\% 16$, tecrübe ettiğinden dolayı elma yetiştiren üretici oranı \%15, bakımı kolay olduğu için elma yetiştiren üretici oranı \%6 ve geçim kaynağı olduğu için elma yetiştiren üretici oranı ise $\% 5$ olarak belirlenmiştir. Incelenen işletmelerde yetiştiricilerin büyük bir kısmı (\%78.9) bitki deseninde değişiklik düşündüğünü elma yetiştirmekten vazgeçmek istediklerini ifade ederken bu durumun en önemli sebebi olarak ise \%53.6 ile gelir olmamasını, \%37.5 ile alıcı olmamasını ve \%8.9 ile verim olmamasını öne sürmüşlerdir. Yetiştiricilerin \%18.8'inin durum ne olursa olsun elma yetiştirmeye devam etmek istedikleri ve \%2.3'ünün ise bu konu hakkında kararsız oldukları sonucuna varılmıştır. Türkiye'de üretimi yapılan başlıca elma çeşitleri Golden, Starking, Amasya ve Granny Smith'tir. Türkiye'de en fazla elma ağacı sayısı Starking çeşidine aittir (Sezen, 2021). Incelenen işletmelerin tamamına yakınında (\%97.8) yetiştiricilerin yetiştirdiği elmanın çeşit adını bildiği, çok az bir kısmında (\%2.2) çeşit adını bilmedikleri belirlenmiştir. Yetiştiricilerin \%29.2'sinin yetiştiriciliğini yaptığı elmanın çeşit özelliğini bildiği, \%65.9'unun ise çeşit özelliğini bilmediği sonucu ortaya çıkmıştır. Çeşit özelliğini bilerek yetiştiricilik yapan işletme sahipleri çeşit özelliklerini tanımlarken verimi yüksek ve hastalıklara zararlılara karşı dayanıklı çeşitler olarak tanımlama yapmışlardır. Incelenen işletmelerde sadece Golden elma yetiştiriciliği yapılma oranı \%57.8 ile ilk sırada yer alırken, bunu Golden ve Starking çeşitleri \%17.9'luk oran ve \%17.4 oran ile Granny Smith çeşidinin izlediği tespit edilmiştir. Yerli elma çeşidi ile yetiştiricilik yapılma oranı ise $\% 4$ olarak belirlenmiştir. Isparta'da Demircan ve ark (2005) tarafından yapılan çalışmada genellikle Golden ve Starking elma çeşitlerinin üretiminin yapıldığı belirlenmiş, yine Isparta'da Erdoğan ve ark (2016) tarafından yapılan çalışmada da \%58.6 oranında Starking, $\% 28.3$ oranında Golden ve \%10.2 oranında ise Granny Smith elma çeşitleriyle üretim yapıldığı belirlenmiştir. Aydoğmuş ve Yılmaz (2010) tarafından Antalya'da elma yetiştiriciliğinin \%36.8 ile Golden, \%28.2 ile Starking ve \%21.5 ile Granny Smith çeşitleriyle yapıldığını rapor etmişlerdir. Karaman'da elma üretiminin yoğun olarak Golden elma çeşidiyle yapıldığı tespit edilmiştir (Karaçayır 2010). Çelik ve Karakaya (2017) Türkiye elma üretiminde Starking elma çeşidinin oranını \%41, Golden elma çeşidinin oranını \%26 ve Granny Smith elma çeşidinin oranını ise \%4 olarak bildirmişlerdir. Kanat ve ark (2017) tarafından yapılan çalışmada Konya ili elma yetiştiriciliğinde öne çıkan çeşitler, Golden, Starking ve Granny Smith olarak belirlenmiştir.

\section{Üreticilerin Elma Yetiştiriciliği ile ilgili Bilgi Kaynakları}

Incelenen işletmelerde dikim kararı verirken hasat dönemindeki piyasa koşulları (talep miktarı, fiyat vb.) hakkında bilgi toplayan yetiştiricilerin oranı \%71.8 olarak belirlenirken, bu durumla ilgili bilgi toplamayan yetiştiricilerin oranı ise \%28.2 olarak belirlenmiştir. Piyasa koşulları hakkında bilgi toplanan kaynağın \%37 oranında diğer elma üreticileri, \%27 oranında alıcı ve pazar ve $\% 9$ oranında ise arkadaş köylüler olduğu belirlenmiştir. Elma üretimi konusunda, tarım il müdürlüğünden bilgi alan yetiştiricilerin oranı $\% 9$, ilaç bayilerinden bilgi alanların oranı \%62.8 ve diğer (diğer üretici köylüler, tanıdıklar vb.) bilgi alanların oranı ise \%78 olarak belirlenmiştir. Karaçayır (2010) yapmış olduğu çalışmada özellikle ilaçlama konusunda elma üreticilerinin büyük bir kısmının (\%46.2) tarım il müdürlüğü teknik elemanlarından bilgi aldıkları belirlenmiştir.

\section{Incelenen Işletmelerde Elmanın Pazarlama Yapısı}

Incelenen işletmelerde üreticilerin, yıllık elma satış miktarı, elma satış fiyatı, elmayı kime sattıkları, elmayı işletmede mi yoksa işletme dışında mı sattıkları, satış şekillerinin nasıl olduğu ve pazarlama giderlerine ait bilgiler verilmiştir. Incelenen işletmelerde elma üretim miktarı işletmeler ortalamasında $17586.75 \mathrm{~kg}$, satılan miktar $14210.54 \mathrm{~kg}$ ve satış fiyatı ise 1.16 Ł olarak belirlenmiştir. Bingöl ilinde $4279.19 \mathrm{~kg}$ elma üretilirken bu değerin \%57.3'ünün (2455.56 kg) ortalama 0.92 Ł/kg fiyatla satıldığı tespit edilmiştir. 
Elazığ ilinde elmanın satış fiyatı $1.25 € / \mathrm{kg}$ olarak belirlenmiş, üretim miktarı $12845.06 \mathrm{~kg}$ ve satış miktarı ise 9202.05 kg olarak gerçekleşmiştir. Elazığ ilinde elma satış miktarının üretim miktarı içindeki payı ise \%71.6 olarak hesaplanmıştır. Malatya ilinde $23058.89 \mathrm{~kg}$ elma üretimi gerçekleşmişken bu değerin \%80.5'i (18583.33 kg) 1.31も fiyatla satışa sunulmuştur (Tablo 7). Isparta ilinde Erdoğan ve ark (2016) tarafından yapılan çalışmada $1.958 .400 \mathrm{~kg}$ elmanın 0.87も'den tüccar ve/veya komisyonculara peşin olarak kilo hesabıyla toptan satıldığı belirlenmiştir. Türkiye'de yetiştirilen elmanın bir kısmı hasattan he-men sonra pazara sunulurken, bir kısmı da depolanarak değişik dönemlerde tüketiciye ulaştırılmaktadır. Her iki duユrumda da pazarlama aşamasında değişik kanalların devre-ye girmesinden dolayı üreticiden tüketiciye gelene ka-dar pazarlama marjları nedeniyle fiyatlar yükselmektedir (Yurdakul, 1996; Oğuz ve Karaçayır, 2009).

Tablo 7. Iller itibariyle elma üretim miktarı, satılan miktar ve satış fiyatı ortalama değerleri

\begin{tabular}{lccc}
\hline iller & Üretilen miktar (kg) & Satılan miktar (kg) & $\begin{array}{c}\text { Ortalama } \\
\text { Satış fiyatı (も/kg) }\end{array}$ \\
\hline Bingöl & 4279.19 & 2455.56 & 0.92 \\
Elazı̆̆ & 12845.06 & 9202.05 & 1.25 \\
Malatya & 23058.89 & 18583.33 & 1.31 \\
Ortalama & 17586.75 & 14210.54 & 1.16 \\
\hline
\end{tabular}

Incelenen işletmelerin \%54'ünde elmanın fabrikaya, \%27'sinde tüccara, \%13'ünde köylüye ve $\% 6$ 'sında ise diğer (Birlik, Toprak Mahsulleri Ofisi (TMO)) gibi birimlere satıldığı tespit edilmiştir. İşletmelerin \%87'sinde elmanın işletmede, \%13'ünde ise işletme dışında satıldığı belirlenmiştir. Incelenen işletmelerin tamamında elma satışının peşin olarak gerçekleştiği saptanmıştır. İşletmelerin tamamında elmaya satıştan önce sınıflandırma (dereceleme) yapılmadığı belirlenmiştir. İncelenen işletmelerde nakliyede $\% 54$ oranında pikap, $\% 46$ oranında ise traktör kullanıldığı belirlenmiştir. Nakliyede kullanılan aracın \%95 oranında yetiştiriciye ait olmadığı ve pazarın uzaklığının ortalama 8.04 km olduğu sonucu bulunmuştur. Incelenen işletmelerde yetiştiricilerin \%56'sı elmanın satış fiyatını belirlerken alıcının teklifini kabul etmek zorunda olduklarını, \%36'sı alıcı ile pazarlık ettiklerini, $\% 6^{\prime}$ sı önce pazar fiyatını öğrenip sonra en yüksek fiyatı değerlendirdiğini ve $\% 2$ 'si ise bu konuyla çok ilgilenmediklerini beyan etmişlerdir. İncelenen işletmelerde yetiştiricilerin \%69'u pazar fiyatını alıcıdan, \%16'sı arkadaş ve tanıdıklarından, \%14'ü düzenli olarak pazara giderek pazardan ve $\% 1$ 'i ise pazar fiyatını öğrenmek için herhangi bir kaynağı takip etmediğini belirtmişlerdir. Yetiştiricilerin beyanları doğrultusunda fiyat belirlenmesinde ürün kalitesinin $\% 90$, işletmenin yeri (konumu) \%5, diğer (alıcı) \%3 ve ürün miktarının \%2 oranında rol oynadığı belirlenirken ödeme zamanı ve destekleme fiyatının ise fiyat belirlemede hiçbir etkisinin olmadığı belirlenmiştir. Incelenen işletmelerde satışta ürün kalitesinin belirlendiğini ifade eden yetiştiricilerin oranı \%61.6, ürün kalitesinin belirlenmediğini ifade edenlerin oranı ise \%38.4 olarak belirlenmiştir. Ürün kalitesinin belirlendiği işletmelerin tamamında ürün kalitesinin alıcı tarafından belirlendiği sonucu tespit edilmiştir. İncelenen işletmelerde yetiştiricilerin \%45'i 1 alıcı ile satış işlemini gerçekleştirdiğini ifade ederken, \%39'u 2 veya 3 alıcıyla, \%16'sı ise 4 veya daha fazla alıcı ile satış işlemini gerçekleştirdiklerini ifade etmişlerdir. İncelenen işletmelerin \%56.9' unda alıcının ürün için önerdiği fiyatının yetersiz bulunduğu durumda alıcı ile pazarlık yapıldıktan sonra fiyatın kabul edildiği, \%43.1'inde ise alıcının ürün için belirlediği fiyatın direk kabul edildiği saptanmıştır. İncelenen işletmelerin tamamında alıcıdan avans kredi alınmadığı tespit edilmiştir.

\section{Üreticilerin Örgütlenme Durumu}

Incelenen işletmelerde yetiştiricilerin \%95.5'inin herhangi bir kooperatife üye olmadıkları belirlenirken \%4.5'inin tarım kredi kooperatifine üye oldukları ancak üye olan yetiştiricilerin tamamının elma üretim ve pazarlaması ile ilgili hiçbir hizmetten faydalanmadıkları sonucu tespit edilmiştir. Incelenen işletmelerde bir pazarlama kooperatifinin pazarlama sorunlarını çözeceğine inanan yetiştiricilerin oranı \%52.9 iken, yetiştiricilerin \%47.1'i ise böyle bir kooperatifin pazarlama sorunlarını çözeceğine inanmadıklarını ifade etmişlerdir. Yetiştiricilerin tamamı hem böyle bir kooperatifin kurulmasında hem de kurulduktan sonra işleyişinde hem üretici hem de alıcılar yönüyle ilgisizlikten dolayı bu girişimin başarılı olacağına inanmadıklarını belirtmişlerdir. Yetiştiricilerin \%85.8'i kooperatifsel bir örgütlenme 
olmadan üreticiler alıcı karşısında birlikte davranarak pazarlık güçlerini artırabilir fikrine katılmadıklarını kooperatifsel bir örgütlenmeye pazarlık noktasında ihtiyaç olduğunu belirtirken, \%14.2'lik bir kısım ise pazarlık noktasında üreticilerin örgütlenmeye ihtiyaç duymayacağı fikrine katıldıklarını beyan etmişlerdir. Çelik ve Karakaya (2017) tarafından Bingöl'de yapılan çalışmada da yetiştiricilerin \%95'inin herhangi bir kooperatife üye olmadıkları ve yetiştiricilerin kooperatifsel bir örgütlenmeye karşı ilgisiz ve isteksiz oldukları belirlenmiştir. Yetiştiricilerin \%11.7'si hükümetin uyguladığı tarım politikalarını genel olarak yetersiz bulurken, \%88.3'ü ise sadece pazarlama ve destekler noktasında bu politikaları yetersiz bulduklarını belirtmişlerdir. Yetiştiricilerin tamamı doğrudan gelir desteği hakkında bilgisi olmadığını ifade etmişlerdir.

\section{incelenen işletmelerde Üreticilerin Elma Yetiştiriciliği ile ilgili Sorunları}

Incelenen işletmelerde yetiştiricilerin elma üretiminde toprak hazırlığı, gübreleme, ilaçlama, fidan, sulama, hasat ve pazarlama konularındaki temel sorunları belirlenmeye çalışılmıştır. Yapılan analiz sonucunda toprak hazırlığının zamanında yapılmaması sorunu \%38, toprak hazırlığı ve ekim konusunda bilgi eksikliği sorunu \%26, alet makine sorunu \%21 ve diğer (hepsi) ise \%15 olarak belirlenmiştir. Incelenen işletmelerin tamamında yetiştiricilerin toprak tahlili yaptırmadığı saptanmış, gübrenin zamanında atılamaması sorunu \%11, gübre fiyatlarının pahalı olması sorunu \%47.1, alet makine sorunu \%9.4, gübreleme konusunda bilgi yetersizliği sorunu \%21.7 ve diğer sorunların (hepsi) oranı \%10.8 olarak belirlenmiştir. Incelenen işletmelerde fidan kalitesindeki sorunların oranı \%68.2, diğer (hepsi) sorunların oranı \%26, fidan temininin zamanında karşılanamaması sorununun oranı \%4.5 ve fidan fiyatlarının yüksek olması sorununun oranı ise \%1.3 olarak belirlenmiştir. İncelenen işletmelerde ilaç fiyatlarının pahalı olması \%42.2, ilaçlama konusunda bilgi yetersizliği \%29.1, diğer (hepsi) \%22 ve alet makine sorunu ise \%6.7 oranında tespit edilmiştir. İncelenen işletmelerde su maliyetinin fazla oluşu \%70.4, diğer (hepsi) sorunlar \%17.7, suyun yetersizliği \%7, sulama konusunda yetersiz bilgi \%3.1 ve alet makine sorunu ise \%1.8 oranında sorun olarak görülmektedir. Incelenen işletmelerde \%91.5 oranında hasat kaybı, \%8.1 oranında hasat ücretlerinin pahalı olması ve $\% 0.4$ oranında ise zamanında hasat yapılamaması sorun olarak görülmektedir. İncelenen işletmelerde hasat işleminde bütün sorunları bir arada sorun olarak gören üretici olmadığı sonucu belirlenmiştir. Incelenen işletmelerde \%72.3 oranında elma satış fiyatlarının düşük olması, \%21 oranında diğer (hepsi) sorunlar, \%6.7 oranında ise depolama sorunu üreticiler açısından öncelikli sorunlar olarak ifade edilmiştir. Aracıların fazla olması, ürünün hemen satılma zorunluluğu ve taşıma masraflarının pahalı olması sorunlarının hiçbir üretici tarafından öncelikli sorun olarak görülmediği sonucu bulunmuştur. Incelenen işletmelerin tamamında kredi kullanılmadığı belirlenmiştir. Bayramoğlu ve ark (2009) tarafından Konya'da yapılan çalışmada; elma üretiminde teknik bilgi yetersizliği, pazarlama bilgisi yetersizliği, su kaynaklarının yetersizliği ve elma fiyatlarındaki dalgalanmalar üreticiler tarafından sorun olarak bildirilmiştir. Bingöl'de Çelik ve Karakaya (2017)'nın yapmış olduğu çalışmada ise; üreticilerin hastalık ve zararlıları, devlet desteklerini, sulama sistem ve yöntemlerini, ilaçlama işlemlerini, alet makine kullanımını, pazarlamayı ve tüm faktörlerin hepsini bir arada sorun olarak gördüklerini ifade ettikleri belirlenmiştir. Iğdır ilinde yapılan çalışmada; elma işletmelerinin sorunları olarak; işletmelerin küçük ve parçalı olması, çeşit seçimi ve yetiştirme tekniği açısından bilinçli hareket edilmemesi, girdi kullanımı, ambalajlama, etiketleme ve muhafazaya gereken önemin verilmemesi, ürünün üretim ve pazarlamasına yönelik üretici örgütlenmesinin olmaması, depolama kapasitesinin yetersiz, mevcut depoların eski teknoloji olması, ürünü tam ya da yarı mamul olarak işleyecek yeterli sayıda tesisin bulunmaması, ilin önemli iç pazarlara uzak olması tespit edilmiştir (Ertürk ve ark., 2016). Türkiye elma ticaretinde pazarlama sorunu olduğu ve özellikle Türkiye'nin mevcut dış ticaret potansiyelini kullanamadığından dolayı elma üretimini artıramadığı sonucu saptanmıştır. Üretim açısından potansiyeli yüksek olarak değerlendirilen Türkiye'nin bu potansiyelini elma ihracatına olumlu yansıtamadığı vurgulanmıştır (Niyaz ve Demirbaş, 2011; Aras, 2015; Bashimov, 2016). Sezen (2021) yapmış olduğu çalışmada; Türkiye elma üretimindeki temel sorunları; üretim kalitesinin düşüklüğü, yetiştirilen çeşitlerin ihracata uygun olmaması, altyapı imkânlarının kısıtlılığı ve elma işletmelerinin küçük ölçekli olması ve işletmelerin etkinliği olarak sıralamıştır.

\section{Sonuç ve Öneriler}

Elma tarımı ile uğraşan bireylerin genelde orta yaş grubunda (41-60 yaş) olduğu ve okuryazarlık oranının Türkiye ortalamasının üzerinde olduğu sonucuna varılmıştır. Elma yetiştiriciliği deneyim süresinin genel tarım deneyim süresi içindeki payı (\%82) dikkate alındığında işletmelerin elma yetiştiriciliği ile birlikte meyve yetiştiriciliğine başladıkları kanısına 
varılmıştır. İncelenen işletmelerin büyük bir kısmında elma ile birlikte ağırlıklı olarak diğer meyvelerin (kayısı ceviz badem) de yetiştirildiği belirlenmiştir. Bölgede tarım dışı çalışma yapıldığı ve genellikle esnaflık yapan üreticilerin olduğu sonucuna varılmıştır. Üreticilerin büyük bir kısmının Bağ-Kur'lu olduğu belirlenmiş, incelenen elma bahçelerinin ortalama 12 yaşında olduğu, büyük oranda üreticinin kendi mülkü olduğu ve üreticilerin beyanları esas alınarak; bahçelerin düz, verimli ve sulu olduğu sonucu belirlenmiştir. Incelenen işletmelerde dekara ortalama elma verimi $627.65 \mathrm{~kg} / \mathrm{da}$ olarak hesaplanmış olup, verim değerinin tesis ömrü arttıkça azaldığı sonucuna ulaşılmıştır. İncelenen işletmelerin alet makine varlığı göz önüne alındığında; TRB1 bölgesi elma yetiştiriciliği yapılan işletmelerde makineli tarımın yüksek oranda kullanıldığı kanısına varılmıştır. Üreticilerin yarıdan fazlasının alışkanlık olduğu için elma yetiştirdiği, elma yetiştiriciliğini gelir getirmemesinden dolayı büyük bir kısmının bırakmak istediği sonucuna varılmıştır. Üreticilerin tamamına yakınının çeşit adını bilerek, ancak büyük bir kısmının ise çeşit özelliğini bilmeden üretim yaptıkları sonucuna varılmıştır. Türkiye elma üretim yapısına uygun olarak golden ve starking çeşitlerinin bölge üreticileri tarafından da yüksek oranda tercih edildiği belirlenmiştir. Üreticilerin elma üretiminde dikimden hasata kadar elma ile ilgili diğer üreticiler ve zirai ilaç bayilerinden bilgi topladıkları belirlenmiştir. Incelenen işletmelerde; işletmeler ortalamasında üretilen elmanın yaklaşık olarak \%81'inin kg'ı 1.16も'den tüm işletmelerde peşin olarak ve çoğunlukla bahçede, fabrikalara satıldığı belirlenmiştir. Ürün satışında sınıflandırma yapılmadığı, satış fiyatının ve ürün kalitesinin alıcı tarafından belirlendiği, işletmelerin yarısına yakınında (\%45) ürün satışının sadece 1 alıcı ile gerçekleştiği ve işletmelerin tamamında alıcıdan avans kredi alınmadığı belirlenmiştir. İncelenen işletmelerde yetiştiricilerin çok büyük bir kısmının herhangi bir kooperatife üye olmadıkları belirlenirken \%4,5'inin tarım kredi kooperatifine üye oldukları ancak üye olan yetiştiricilerin tamamının elma üretim ve pazarlaması ile ilgili hiçbir hizmetten faydalanmadıkları sonucu tespit edilmiştir. Yetiştiricilerin pazarlama ve kooperatifsel örgütlenme noktasındaki düşünceleri birlikte ele alındığında, kooperatifsel bir örgütlenmeye pazarlama noktasında ihtiyaç olduğunu ancak böyle bir örgütlenme girişiminin ilgisizlikten dolayı oluşamayacağını düşündükleri kanısına varılmıştır. Yetiştiricilerin genel olarak elma üretimindeki sorunları sorulduğunda, pazarlama sorunu içinde elma alıcı sayısının az ve elma satış fiyatının çok düşük olması, girdi fiyatlarının çok yüksek olması, desteklemelerin az veya yetersiz ve gübreleme, ilaçlama konularında teknik bilgi eksikliği gibi cevaplar alınmış, bu sorunların çözümü noktasında ise yetiştiricilerin, pazarlama ve girdi fiyatları noktasında destek, gübreleme ve ilaçlama konularında eğitim, taş ocakları ve sanayi fabrikalarının tarım ürünlerine verdiği kalite zararına önlem alınması gibi beklentiler içinde oldukları sonucuna varılmıştır.

Üreticilerin beklentilerine cevap verebilecek kooperatif kurmaları sağlanmalı veya mevcut birliklere katılımları teşvik edilerek ürettikleri ürünlerin bir kısmını okul, hastane, bakımevleri gibi toplu yerlere doğrudan pazarlamaları sağlanarak hem pazarlama sorunları hem de kazanç sağlama isteklerine cevap verilebilir.

Bölgede üretilen elmanın dış pazarlara ihracatı konusunda bölgesel stratejilerin geliştirilmesi gerekmektedir. ilgili kurum ve kuruluşlar ile elma üretimiyle doğrudan ya da dolaylı ilgilenen tarafların katılımıyla çeşitli toplantılar yapılmalı, elma konusunda bölgesel bir vizyon geliştirilmeli ve bu anlamda stratejik amaç ve hedefler belirlenmelidir.

Yetiştiricilerin büyük bir kısmı devlet desteği ve teşviklerin elma yetiştiriciliği için yetersiz olduğunu düşünmektedirler. Bu anlamda Türkiye elma üreticileri için hangi tür destek ve teşviklerin var olduğuna yönelik elma üreticileri özelinde bir araştırma yapılarak kullanıma sunulması son derece önemlidir.

Zirai mücadele ve ilaç kullanımı ile ilgili eğitim ve yayım programları yapılmalı, bilinçli bir ilaçlama yapılması sağlanmalı, yanlış ve aşırı ilaçlama gerekli denetimler yapılarak engellenmelidir.

TRB1 bölgesinde, tarım bakanlığı ve ilgili araştırma enstitülerince, elma üretiminin geliştirilmesine yönelik olarak örnek bahçeler tesis edilerek ve demonstrasyon çalış־maları yürütülerek üreticilerin bilinç ve eğitim düzeyi artırılmalıdır.

Ulusal ve uluslararası pazar talebi olan elma çeşit-lerinin üreticilere tanıtımı yapılarak, bu çeşitlerin yetiştiriciliğinin yapılması sağlanabilir.

\&: Çalışma sorumlu yazarın doktora tez verilerinden üretilmiştir.

Çıkar Çatışması Beyanı: Makale yazarları aralarında herhangi bir çıkar çatışması olmadığını beyan ederler.

Araştırmacıların Katkı Oranı Beyan Özeti: Yazarlar makaleye eşit oranda katkı sağlamış olduklarını beyan ederler. 


\section{Kaynaklar}

Abdul-Kareem, MM. 2015. Technıcal Efficiency Of Cassava Production In The Savannah Zone Of Northern Ghana; Stochastıc Frontıer Analysıs. The Republic Of Turkey Harran University Graduate School Of Natural And Applied Sciences. Msc Thesis Department Of Agricultural Economics Sanlıurfa 2015 S.90

Alemu, S. H., L. van Kempen, and R. Ruben. 2017. Explaining Technical Inefficiency and the Variation in Income from Apple Adoption in Highland Ethiopia: The Role of Unequal Endowments and Knowledge Asymmetries." Journal of Agriculture and Rural Development in the Tropics and Subtropics 118 (1): 31-43.

Aras, i. 2015. Elma Sektörü Raporu-Karaman, Mevlana Kalkınma Ajansı, Konya.

Arısoy, H., Oğuz, C. 2005. Tarımsal Araştırma Enstitüleri Tarafından Yeni Geliştirilen Buğday Çeşitlerinin Tarım İşletmelerinde Kullanım Düzeyi ve Geleneksel Çeşitler ile Karşılaştırmalı Ekonomik Analizi - Konya illi Örneği, T.C. Tarım ve Köyişleri Bakanlığı Tarımsal Ekonomik Araştırma Enstitüsü Yayınları, Yayın No: 130, ISBN: 975-407174-8, Ankara.

Armagan, G. A. Ozden 2007. Determinations of total factor productivity with CobbDouglas production function in agriculture: The case of Aydin-Turkey, J. Applied Sci, 7(4), 499- 502.

Aydın, B. 2014. Trakya Bölgesinde Faaliyet Gösteren Tarım İşletmelerinin Yapısal Özellikleri Ve Etkinliklerinin Belirlenmesi. Doktora Tezi, Tarım Ekonomisi Anabilim Dalı, T.C. Namık Kemal Üniversitesi Fen Bilimleri Enstitüsü, Tekirdağ 2014 s. 150

Aydoğmuş, F. Yılmaz, İ. 2010. Antalya ilinde bodur, yarı bodur ve çöğür anaç kullanılarak yapılan elma üretiminin ekonomik analizi. Akdeniz Üniversitesi Ziraat Fakültesi Dergisi 23: 127-135.

Aytop, Y, Akbay, C. 2018. Baharatlık Kırmızı Biber (Maraş Biberi) Üretiminin Ekonomik Analizi. Türk Tarım ve Doğa Bilimleri Dergisi, 5 (4): 455-464

Bai, X.; Salim, R.; Bloch, H. 2019. Environmental Efficiency of Apple Production in China: A Translog Stochastic Frontier Analysis. Agric. Resour. Econ. Rev. 2019, 48, 199-220.

Bashimov, G. 2016. Elma ihracatında Türkiye'nin Karşılaştırmalı Üstünlüğü. Adnan Menderes Üniversitesi Ziraat Fakültesi Dergisi 2016; 13(2) : 9 - 15
Bayramoğlu, Z. Bozdemir, M. 2018. Dane Mısır Üretiminde Kaynak Kullanım Etkinliğinin Belirlenmesi: Konya ìli Örneği. Selçuk Üniversitesi Ziraat Fakültesi Tarım Ekonomisi Anabilim Dalı. ISBN: 978-60582785-9-2, 1. Basım, Mart 2018, Atlas Akademi, s. 237.

Bayramoğlu, Z. Çelik, Y. Oğuz, C. 2009. Konya Illinde Elma Üretiminin Mevcut Durumu ve Gelişme Olanakları. Tarım Bilimleri Araştırma Dergisi 2 (1):11-15.

Binici, T., C.R. Zulauf, O.O. Kacıra ve B. Karlı, 2006. Assessing the efficiency of cotton production on the Harran Plain, Turkey. Outlook on Agriculture, 35(3): 227-232.

Çakırlı, C. 2017. Mersin İli Tarsus İlçesi Narenciye İşletmelerinin Sosyoekonomik Analizi. T.C. Kahramanmaraş Sütçü İmam Üniversitesi Fen Bilimleri Enstitüsü. Yüksek Lisans Tezi Tarım Ekonomisi Anabilim Dalı. Kahramanmaraş, 2017, s. 70

Çelik, A. ve Karakaya, E. 2017. Bingöl illi Adaklı İlçesi Elma Üreticilerinin Tarımsal Ilaç Kullanımında Bilgi Tutum ve Davranışlarının Değerlendirilmesi ve Ekonomik Analizi. Türk Tarım ve Doğa Bilimleri Dergisi 4(2): 119-129.

Çiçek, A., Erkan, O. 1996. Tarım Ekonomisinde Araştırma ve Örnekleme Yöntemleri. Gaziosmanpaşa Üniversitesi, Ziraat Fakültesi Yayınları No 12, Ders Notları Serisi 6, 118s.

Demircan V, Yılmaz H, Binici T., 2005. Isparta İlinde Elma Üretim Maliyeti ve Gelirinin Belirlenmesi. Tarım Ekonomisi Dergisi, 11(2):71-80.

Erdoğan, E., Adanacıoğlu, H., Örmeci Kart, M. 2016. Elma Üretiminde Pazarlama Etkinliğinin Belirlenmesi Üzerine Bir Araştırma: Isparta Senirkent İlçesi Örneği . KSÜ Doğa Bilimleri Dergisi, 19 (2) , 152-159

Erturk, Y.E., Karadaş, K. ve Geçer, M.K. 2016. Iğdır İlinde Elma Üretimi ve Pazarlaması. Meyve Bilimi, 1(Özel Sayı): 38-43.

FAO, 2017. Gıda ve Tarım Örgütü. Elma Üretim İstatistikleri. (http://www.fao.org/faostat) (Erişim tarihi: 15.02.2021)

FAO, 2019. Gıda ve Tarım Örgütü. Elma Üretim İstatistikleri. (http://www.fao.org/faostat) (Erişim tarihi: 15.02.2021)

Gence, F. 2019. Kahramanmaraş ilinde Çerezlik Ayçiçeği Üretim Faaliyetinin Ekonomik Analizi. T.C. Kahramanmaraş Sütçü İmam Üniversitesi Fen Bilimleri Enstitüsü. Yüksek 
Lisans Tezi Tarım Ekonomisi Anabilim Dalı, Kahramanmaraş, 2019 s. 51

Gözener, B. 2013. Tr83 Bölgesinde Sığır Yetiştiriciliğine Yer Veren İşletmelerin Ekonomik Analizi Ve Teknik Etkinlik. Gaziosmanpaşa Üniversitesi Fen Bilimleri Enstitüsü Tarım Ekonomisi Anabilim Dalı, Doktora Tezi.

Gül, M. 2005. Technical efficiency and productivity of apple farming in Antalya province of Turkey. Pakistan Journal of Biological Sciences 8:1533-1540.

Hazneci, K. 2015. Şeker Pancarı Ve Buğday Tohumluğu Üretiminde Teknik Etkinlik Ve Fiyat Değişkenliğinin Iş̧letme Organizasyonuna Etkisi. T.C. Ondokuz Mayıs Üniversitesi Fen Bilimleri Enstitüsü. Tarım Ekonomisi Anabilim Dalı, Doktora Tezi, Samsun, 2015 s. 253

Kaçıra, ÖÖ. 2007. Mısır Üretiminde Etkinlik Analizi. Çukurova Üniversitesi, Fen Bilimleri Enstitüsü, Tarım Ekonomisi Anabilim Dalı, Doktora Tezi. Adana.

Kanat, Z. Çelik, Y. Çay, Ş. 2017. Konya İlinde Bodur ve Yarı Bodur Elma Üretiminin Maliyet Analizi. Selcuk J Agr Food Sci, (2017) 31 (1), 56-62

Karaçayır, HF. 2010. Elma Üretimi Yapan Tarım İşletmelerinde Tarımsal ilaç Kullanımında Yayım Yaklaşımları; Karaman İli Örneği. T.C. Selçuk Üniversitesi Fen Bilimleri Enstitüsü. Yüksek Lisans Tezi Tarım Ekonomisi Anabilim Dalı Konya, 2010 s. 158

Kaya, E., Akın, A., Keskin, H.A. 2009. Ticari 100 Dekar tam bodur 4 yaşındaki M9 anaçlı meyve bahçesinde ortalama bir yıllık bakım masrafları. Tarım Bilimleri Araştırma Dergisi 2(1): 69-74, 2009.

Kaynaş, K., Şeker, M., Gündoğdu, M. A., Sakaldaş, M., Akçal, A., İzmir, A. 2009. Çanakkale'de Elma Yetiştiriciliğinin Sorunları ve Çözüm Önerileri. International Journal of Agricultural and Natural Sciences, 2(1), 3539.

Ma, W. A. Renwick, P. Yuan, N. Ratna 2018. Agricultural cooperative membership and technical efficiency of apple farmers in China: An analysis accounting for selectivity bias Food Policy, 81 (2018), pp. 122-132

Mesci, O. 2018. Isparta İlinde Arazi Toplulaştırması Yapılan Alanlardaki Tarım İşletmelerinin Ekonomik Analizi. T.C. Süleyman Demirel
Üniversitesi Fen Bilimleri Enstitüsü, Yüksek Lisans Tezi Tarım Ekonomisi Anabilim Dalı Isparta - 2018, s. 87

Mesci, O., Karlı, B. 2018. Isparta illinde Arazi Toplulaştırması Yapılan Alanlardaki Tarım İşletmelerinin SosyoEkonomik Analizi. Mustafa Kemal Üniversitesi Ziraat Fakültesi Dergisi 23(1):106-114

Niyaz, Öc., Demirbaş, N. 2011. Türkiye Yaş Meyve Üretim ve İhracatının Son On Yıllık Döneminin Değerlendirilmesi. Tarım Ekonomisi Dergisi 17 (1): 37-45.

Oğuz, C., Karaçayır, H. F. 2009. Türkiye'de Elma Üretimi, Tüketimi, Pazar Yapısı ve Dış Ticareti. International Journal of Agricultural and Natural Sciences, 2(1), 4149.

Osmani, M., Kambo, A. 2019. Efficiency of apple small-scale farming in Albania. A Stochastic Frontier Approach. NEW MEDIT N. 2/2019

Sezen, S. 2021. Dünyada ve Türkiye'de Elma Yetiştiriciliği, Sorunlar ve Çözümler. (https://www.hortiturkey.com) (Erişim tarihi: 16.02.2021).

Şenyurt, M., Kalkışım, Ö. ve Karadeniz, T. 2015. Gümüşhane Yöresinde Yetiştirilen Bazı Standart ve Mahalli Elma (Malus communis L.) Çeşitlerinin Pomolojik Özellikleri. Akademik Ziraat Dergisi, 2015, 4(2): 59-64

TÜiK, 2010. Türkiye İstatistik Kurumu. Bitkisel üretim istatistikleri. (www. tuik.gov.tr) (Erişim tarihi: 17.02.2021)

TÜiK, 2019. Türkiye İstatistik Kurumu. Bitkisel üretim istatistikleri. (www. Tuik.gov.tr) (Erişim tarihi: 17.02.2021)

Ulu Ö, Engindeniz S, Özden A, 2016. İzmir'de Bamya Üretiminde Girdi Kullanım Etkinliğinin Analizi, Tarım Ekonomisi Dergisi Cilt:22 Sayı:2 Sayfa:69-76

Yalçın Sever, C. 2019. En çok starking ve golden üretiyoruz. (http://www.turktarim.gov.tr) (Erişim tarihi: 15.02.2021)

Yıkar E, 2003. Elma. T.E.A.E. Bakış, Sayı: 4, Nüsha: 7, Eylül, Tarımsal Ekonomi Araştırma Enstitüsü, Ankara.

Yurdakul O, 1996. Tarım Ürünleri Pazarlaması. Çukurova Üniversitesi Ziraat Fakültesi. Genel Yayın No: 39, Adana. 